\title{
Ethmoid Sinus Primary Ectopic Meningioma
}

National Cancer Institute

\section{Source}

National Cancer Institute. Ethmoid Sinus Primary Ectopic Meningioma. NCI Thesaurus.

Code C5309.

An extremely rare meningioma that arises as a primary ectopic tumor in the ethmoid sinus. 